Original Research Article

\title{
The effect of docosahexaenoic acid (DHA) supplementation on experimental depression in mice
}

\author{
Tulika Singhal*, Saroj Kothari
}

Department of Pharmacology, Gajra Raja Medical College, Gwalior, Madhya Pradesh, India

Received: 21 November 2017 Accepted: 28 December 2017

\section{*Correspondence to:}

Dr. Tulika Singhal,

Email: sdrtulika02@gmail.com

Copyright: (C) the author(s), publisher and licensee Medip Academy. This is an openaccess article distributed under the terms of the Creative Commons Attribution NonCommercial License, which permits unrestricted noncommercial use, distribution, and reproduction in any medium, provided the original work is properly cited.

\begin{abstract}
Background: Depressive disorder is a prevalent psychiatric disorder, which affects $21 \%$ of the world population. Many drugs which are available as effective antidepressants produce various side effects like sedation weight gain postural hypotension etc., so there is need to develop novel compounds with minimized side effects. Hence this study was aimed to investigate the antidepressant activity of DHA, an omega-3 polyunsaturated fatty acid in albino mice.

Methods: Animals were divided into four groups, consisting six mice in each group. Out of these, group I served as control (2\% gum acacia), group II and III received test drug in two different doses $200 \mathrm{mg} / \mathrm{kg}$ and $300 \mathrm{mg} / \mathrm{kg}$ respectively and group IV received fluoxetine $(20 \mathrm{mg} / \mathrm{kg})$ as standard drug. To determine the antidepressant-like activity, we used forced swim test and tail suspension test in mice. These methods are based on the observation that a mouse show alternating agitation and immobility; the immobility is indicative of a state of depression.

Results: DHA produced significant antidepressant effect at all the doses, as indicated by reduction in immobility times as compared to control in both FST and TST. $(\mathrm{P}<0.05)$ The efficacy of DHA at dose of $300 \mathrm{mg} / \mathrm{kg}$ was comparable with that of fluoxetine. DHA at $200 \mathrm{mg} / \mathrm{kg}$ dose showed significantly less antidepressant activity compared to fluoxetine. $(\mathrm{P}<0.05)$.

Conclusions: The result specifies that compared to two doses of DHA $(200 \mathrm{mg} / \mathrm{kg}$ and $300 \mathrm{mg} / \mathrm{kg}$ ), higher dose of DHA found as an effective dose for treating depression produced due to stress.
\end{abstract}

Keywords: Docosahexaenoic acid, Forced swim test, Fluoxetine, Tail suspension test

\section{INTRODUCTION}

Depression is one of the leading causes of global disease burden and disability affecting $10-15 \%$ of the population at some time in their lives. ${ }^{1}$ The high prevalence of suicide in depressed patients (up to 15\%), coupled with complications arising from stress and its effects on the cardiovascular system, have suggested that it will be the second leading cause of death by the year 2020 and studies show depression as a contributory factor to fatal coronary disease. $^{2}$

It is a heterogeneous disorder that affects a person's mood, physical health, and behaviour. Patients with major depression have symptoms that reflect changes in brain monoamine transmitters, specifically norepinephrine, serotonin, and dopamine. ${ }^{2}$ The current modalities of treatment for depression include tricyclic antidepressants (TCAs), monoamine oxidase inhibitors (MAOIs) and selective serotonin reuptake inhibitors (SSRIs). These antidepressant medications have many adverse effects like sedation, weight gain, sexual disturbances and delayed onset of therapeutic effect. ${ }^{3}$ This latency is problematic as it prolongs the impairments associated with depression, leaves patients vulnerable to an increased risk of suicide, increases the likelihood that a patient will prematurely discontinue therapy and increases medical costs associated with severe depression. ${ }^{4}$ Thus, there is continuous search for newer novel compounds that have better efficacy or can augment the effect of conventional antidepressants in these patients. 
Docosahexaenoic acid (DHA) is an omega-3 derivative of alpha-lenolenic acid (ALA), containing 22 carbons and six double bonds in their structure. It is high quality easily digestible nutrient mostly found in marine algae, fatty fish like salmon, fish oil, mother's milk and at low amount in meat and egg. ${ }^{5,6}$ DHA is a primary structural component of the human brain, cerbral cortex, skin, sperm, testicles and retina. ${ }^{7}$ DHA is the major PUFA in the neuronal membrane. DHA affects serotonergic and dopamenergic neurotransmission and is thus expected to positively influence the various neuropsychiatric disorders. ${ }^{8,9}$

At present there are a number of formula feeds for infants and school going children containing DHA are available in market. Therefore present study was planned to study the effect of pure DHA supplementation in depression and, these effects are compared with the standard antidepressants drugs, respectively.

\section{METHODS}

All animals were available in animal house of Department of Pharmacology GR medical college Gwalior. Mice were housed in clean polypropylene cages; mice were accommodated in each cage in a controlled environment $\left(26^{\circ}-28^{\circ} \mathrm{C}\right)$ with a 12 hour light and dark cycle and provided with food and water.

The experimental protocol was approved by institutional Animal Ethics Committee (IAEC) of G. R. M. C. Gwalior registration no: 846/GO/Ere/S/04/CPCSEA.

DHA (IUPAC name: all cis- docosa-4,7,10,13,16,19-hexaenoic acid, trivial name- Cervonic acid, chemical formula: C22H32O2, and molecular weight: 328.488 ) was obtained from Green Heaven India (An Herbal Manufacturing Unit). Fluoxetine (Cadila Pharma) was purchased from the medical stores.

\section{Experimental procedures}

The study was carried out in 24 male Albino mice weighing $30-40 \mathrm{~g}$. The animals were randomly divided into 4 groups of 6 mice each. The animals in group 1 (GA10) were given $0.5 \mathrm{ml}$ of the vehicle orally $2 \%$ GA suspension. Animals in group 2 (DHA200) and group 3 (DHA300) were administered DHA $200 \mathrm{mg} / \mathrm{kg}$ and $300 \mathrm{mg} / \mathrm{kg} \mathrm{p}$. o. suspended in $0.5 \mathrm{ml}$ of $2 \%$ gum acacia suspension respectively. Animals in group 4 (FXT20) were administered fluoxetine $20 \mathrm{mg} / \mathrm{kg}$ p. o. which is a known antidepressant. All the groups received the respective treatments for a period of 30 days. On the $30^{\text {th }}$ day, $1 \mathrm{~h}$ after administration of the drug the effect of the drugs on depression recorded by FST and TST.

\section{Forced swim test (FST)}

This paradigm was performed as described previously Porsolt et al and Siuciak et al with some modifications and presently considered a standard method. ${ }^{10-13}$ Depression was produced in albino mice by forcing them to swim individually in a glass jar (diameter $20 \mathrm{~cm}$, height $30 \mathrm{~cm}$ ) containing fresh water of $20 \mathrm{~cm}$ height and maintained at $25^{\circ} \mathrm{C} \pm 1^{\circ} \mathrm{C}$. Rats were placed in an acrylic cylinder for 15 min (pretest session) after 30 day treatment. After 24 hours of the pretest session, the animals were once again exposed to same condition for $5 \mathrm{~min}$ (test session). Between the pretest session and main session drug solutions were administered two times as follows: just after the pretest session and 1 hour before the main test. A rat was judged immobile if it remained floating in the water, except for small movements to keep its head above the water. A decrease in the duration of immobility is indicative off an antidepressant like effect. Following every session, the animal were removed from the cylinder, dried with towels and placed in heated cage for 15 min before returning to their home cage.

\section{Tail suspension test (TST)}

Tail suspension test (TST) was performed according to Steru et al. ${ }^{14}$ Mice were suspended on the edge of a table, $50 \mathrm{~cm}$ above the floor, with the help of an adhesive tape placed approximately $1 \mathrm{~cm}$ from the tip of the tail on the $30^{\text {th }}$ day 1 hour after drug administration. Immobility time was recorded during $6 \mathrm{~min}$ period. The standard immobility period for tail suspension method was $3 \mathrm{~min}$. The animals are considered to be immobile when it did not show any movement of the body and hanged passively.

\section{Statistical analysis}

Values obtained for FST and TST were given as mean \pm SEM. All the groups were analysed by one-way ANOVA followed Tukey's multiple comparison test. P $<0.05$ was considered statistically significant.

\section{RESULTS}

\section{Forced swimming test}

DHA200 and DHA300 significantly lowered the mean immobility time as compared to GA10 ( $\mathrm{p}<0.05)$. Effect of DHA300 was more than DHA200 but it was statistically not significant. Standard drug FXT20 significantly decreased the mean immobility time as compare to control and DHA200 ( $\mathrm{p}<0.05)$. Anti-depressant effect of DHA300 was comparable $(\mathrm{p}>0.05)$ with FXT20.

\section{Tail suspension test}

Figure 1 shows that DHA200 and DHA300 significantly lowered the mean immobility time as compared to GA10 $(p<0.05)$. The effect of DHA300 was more than DHA200 but was statistically not significant. Standard drug FXT10 also showed significantly decreased mean immobility time as compare to control and DHA200 ( $\mathrm{p}<0.01)$. Antidepressant effect of DHA300 was comparable $(p>0.05)$ with FXT20. 
Table 1: Effect of Docosahexaenoic Acid (DHA) on immobility period in forced swim test in mice.

\begin{tabular}{|lll|}
\hline $\begin{array}{l}\text { Groups } \\
\text { no. }\end{array}$ & $\begin{array}{l}\text { Group } \\
\text { name }\end{array}$ & $\begin{array}{l}\text { Mean immobility period } \\
\text { (sec.) }\end{array}$ \\
\hline I & GA10 & $121.83 \pm 3.83$ \\
\hline II & DHA200 & $104.83 \pm 2.90^{\dagger}$ \\
\hline III & DHA300 & $95.83 \pm 2.61^{*}$ \\
\hline IV & FXT20 & $89.50 \pm 4.31^{* \#}$ \\
\hline
\end{tabular}

GA10 $=$ Gum acacia $10 \mathrm{ml} / \mathrm{kg} ;$ DHA200 and DHA $300=$ Docosahexaenoic acid $200 \mathrm{mg} / \mathrm{kg}$ and $300 \mathrm{mg} / \mathrm{kg}$ respectively; FXT20 = Fluoxetine $20 \mathrm{mg} / \mathrm{kg}$ (standard drug). Each group consists of 6 animals $(n=6)$. Values are mean \pm SEM, $d f=3,20$ $\mathrm{F}=16.28 * \mathrm{p}<0.01$ as compared to GA10 $\dagger \mathrm{p}<0.05$ as compared to GA10 \#p $<0.05$ as compare to DHA200

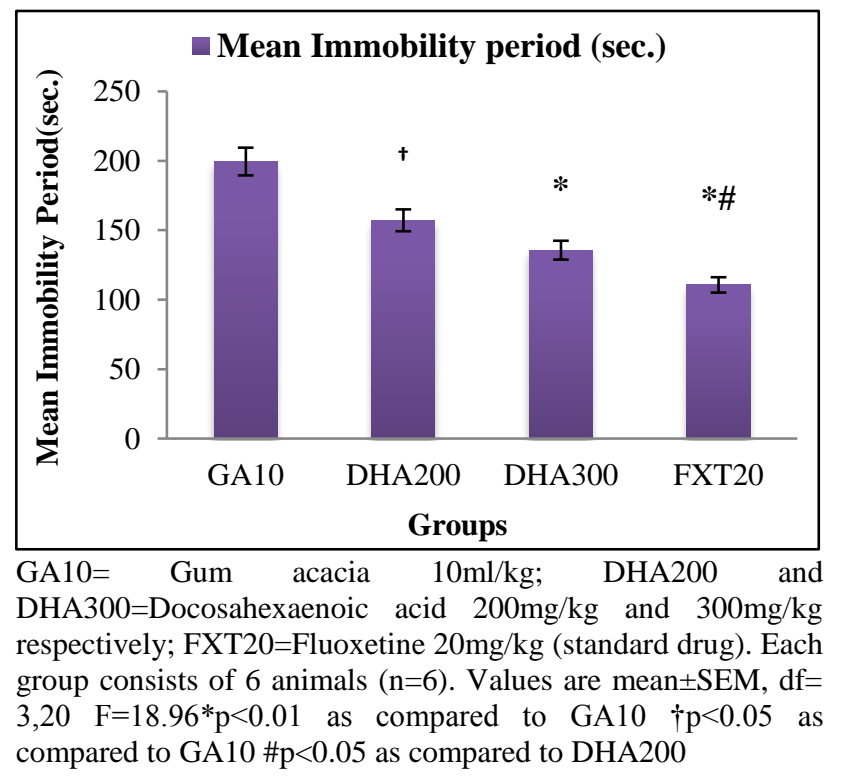

Figure 1: Effect of DHA on mean immobility period in tail suspension test in mice.

\section{DISCUSSION}

The present study was conducted to assess the antidepressant activity of DHA in albino mice by using FST and TST methods. Stress plays an important role in developing depression. FST and TST animal models are quite sensitive and create physical stress and there by leading to depression. These models of depression provide a rapid and reliable behaviour screening test for antidepressants. Both these models are widely used to screen new antidepressant drugs. ${ }^{15}$ Fluoxetine was used as a standard drug for both models in this study.

In our study DHA at the dose of $200 \mathrm{mg} / \mathrm{kg}$ and $300 \mathrm{mg} / \mathrm{kg}$ and standard drug fluoxetine showed significant reduction in immobility time in both anti-depressant models i.e. FST and TST. $(\mathrm{p}<0.01)$ Fluoxetine showed significant $(\mathrm{p}<0.05)$ anti-depressant activity as compared with control and DHA $200 \mathrm{mg} / \mathrm{kg}$. The effect of DHA $300 \mathrm{mg} / \mathrm{kg}$ was comparable $(\mathrm{p}>0.05)$ with fluoxetine.
Studies have shown that DHA is a primary structural component of the human brain and retina. Its deficiencies are associated unipolar depression. ${ }^{16}$

Antidepressant activity of DHA in our study is in accordance with Wietrzych-Schindler, et al who evaluated that after administration on DHA in 3\% ethanol by intraperitoneal injections at volume/weight ratio $3 \mathrm{~mL} / \mathrm{kg}$ for 2 days show significant decrease in immobility period in forced swim test. ${ }^{17}$ Antidepressant effect of DHA might be due to its effect on monoamine neurotransmitter systems, red blood cell membranes and HPA axis, or may be due to increase release of glial cell line derived neurotrophic factor (GDNF). ${ }^{18,19}$ There are many human studies which show the effect of DHA on depression. Smith et al. conduct an 8-week open-label pilot trial of low-dose DHA, $(260 \mathrm{mg}$ or $520 \mathrm{mg} /$ day) in 28 patients with major depressive disorder. ${ }^{20}$

All the above studies revealed the possible mechanism of anti-depressant action of DHA. Furthermore in-vivo and in-vitro studies are required to evaluate the actual mechanism of anti-depressant effect of DHA.

The results of this experimental evaluation after the collection of data and its analysis confirm the antidepressant activity of DHA. However, the study has its share of limitations. There is need to conduct further invivo study with more number of animals and in-vitro experiments like receptor density assay and ACTH hormone assay for antidepressant activity, so as to know the exact mechanism of anti-depressant activity of DHA.

\section{ACKNOWLEDGEMENTS}

Authors would like to thank to Green Heaven India (A Herbal Manufacturing Unit), Hingna, MIDC, Nagpur, Maharashtra, India for supplying the investigational drug.

Funding: No funding sources

Conflict of interest: None declared

Ethical approval: The study was approved by the Institutional Animal Ethics committee of G. R. M. C. Gwalior registration no: $846 / G O / E r e / S / 04 / C P C S E A$

\section{REFERENCES}

1. O’Donnell J, Shelton R. Drug Therapy of Depression and Anxiety Disorders In: Brunton LB, Lazo JS, Parker KL, eds. Goodman \& Gilman's The Pharmacological Basis of Therapeutics. $12^{\text {th }}$ Ed. New York, NY: McGraw-Hill; 2005:397-415.

2. Shoeb A, Chowta M, Pallempati G, Rai A, Singh A. Evaluation of antidepressant activity of vanillin in mice. Indian J Pharmacol. 2013 Mar;45(2):141.

3. Matreja PS, Badyal DK, Deswal RS, Sharma A. Efficacy and safety of add on low-dose mirtazapine in depression. Indian J Pharmacol. 2012 Mar;44(2):173.

4. Whooley MA, Simon GE. Managing depression in medical outpatients. N Engl J Med 2000;343:1942-50. 
5. Horrocks LA, Yeo YK. Health benefits of docosahexaenoic acid (DHA). Pharmacological Research. 1999 Sep 1;40(3):211-25.

6. Bradbury J. Docosahexaenoic acid (DHA): an ancient nutrient for the modern human brain. Nutrients. 2011 May 10;3(5):529-54.

7. Guesnet P, Alessandri JM. Docosahexaenoic acid (DHA) and the developing central nervous system (CNS)- Implications for dietary recommendations. Biochimie. 2011 Jan 31;93(1):7-12.

8. De la Presa Owens S, Innis SM. Docosahexaenoic and arachidonic acid prevent a decrease in dopaminergic and serotoninergic neurotransmitters in frontal cortex caused by a linoleic and $\alpha$-linolenic acid deficient diet in formula-fed piglets. J Nutr. 1999 Nov 1;129(11):2088-93.

9. Delion S, Chalon S, Guilloteau D, Besnard JC, Durand G. $\alpha$-Linolenic Acid Dietary Deficiency Alters AgeRelated Changes of Dopaminergic and Serotoninergic Neurotransmission in the Rat Frontal Cortex. J Neurochem. 1996 Apr 1;66(4):1582-91.

10. Jenner PG. Antidepressants: Neurochemical, Behavioral and Clinical Perspectives. J Neurol Neurosur, Ps. 1982 Jun;45(6):574.

11. Siuciak JA, Lewis DR, Wiegand SJ, Lindsay RM. Antidepressant-like effect of brain-derived neurotrophic factor (BDNF). Pharmacol Biochem Be. 1997 Jan 31;56(1):131-7.

12. Butterweck V, Nishibe S, Sasaki T, Uchida M. Antidepressant Effects of Apocynum venetum Leaves in a Forced Swimming Test. Biol. Pharm. Bull. 2001;24(7):848-51.

13. Detke MJ, Lucki I. Detection of serotonergic and noradrenergic antidepressants in the rat forced swimming test: the effects of water depth. Beha Brain Res. 1995 Dec 15;73(1):43-6.
14. Steru L, Chermat R, Thierry B, Simon P. The tail suspension test: a new method for screening antidepressants in mice. Psychopharmacology. 1985 Mar 1;85(3):367-70.

15. Hamilton M. A rating scale for depression. J Neurol Neurosurg Ps. 1960;23:56-62.

16. Kumari J, Yadav S, Sharma V. Dcosahexaenoic Acid: wonder dietary supplement. International J Ther Appl. 2012;(3):25-31.

17. Wietrzych-Schindler M, Szyszka-Niagolov M, Ohta $\mathrm{K}$, Endo Y, Perez E, de Lera AR, et al, Retinoid x receptor gamma is implicated in docosahexaenoic acid modulation of despair behaviors and working memory in mice. Biol. Psychiatry. 2011;69:788e-794e.

18. Jiang LH, Liang QY, Shi Y. Pure docosahexaenoic acid can improve depression behaviors and affect HPA axis in mice. Cellulose. 2012;50:50.

19. Zhang L, Zhu Z, Tan Z, Luo H, Hu X, Li Y. Docosahexaenoic acid induces glial cell-line derived neurotrophic factor release in C6 glioma cells: Implications of antidepressant effects for docosahexaenoic acid. Biochem Bio Res Co. 2017 Aug 7.

20. Smith DJ, Sarris J, Dowling N, O'Connor M, Ng CH. Adjunctive low-dose docosahexaenoic acid (DHA) for major depression: An open-label pilot trial. Nutr Neurosci. 2017 Feb 22:1-5.

Cite this article as: Singhal T, Kothari $\mathrm{S}$. The effect of docosahexaenoic acid (DHA) supplementation on experimental depression in mice. Int J Basic Clin Pharmacol 2018;7:288-91. 